\title{
EFFECT OF POTASSIUM FERTILIZATION ON GROWTH, YIELD AND WATER USE EFFICIENCY OF IRRIGATED POTATO
}

\author{
A.S. Ati* \\ S. M. Nafaou**
}

\section{ABSTRACT}

Studies on the effect of $K$ fertilizers application in increasing water use efficiency (WUE) and decreasing the negative effect of water stress, are quite limited, especially under field conditions. A field experiment was conducted in silty clay loam in the Agricultural Research Station of AbuGraib-Baghdad, Iraq to study the effect of different levels of $K$ fertilizers application on potato (Solanum tuberosum L.) and their role in decreasing negative effect of water stress.

Treatments include four levels of K fertilizer $(0,200,400$ and $600 \mathrm{~kg}$ $\mathrm{K}_{2} \mathrm{SO}_{4} \mathrm{ha}^{-1}$ ) and two levels of irrigation (after depletion of 50 and $75 \%$ of available water). Results revealed the following:-

1. The negative effects of water stress on potato growth and yield decreased by increased application of $K$ fertilizers.

2. $\quad$ Negative effects of water stress on plant quality and WUE were decreased by increasing level of $K$ fertilizer in depletion $75 \%$ of available water, and saving in irrigation water with irrigation scheduling by $9 \%$.

3. Tuber yield, plant height, leaf area and carbohydrates increased with increased $K$ application. Higher $K$ rates improved yield reached to 30.26 and 25.66 t.hal $^{-1}$ in irrigation with 50 and $75 \%$ depletion of available water, respectively.

4. As a conclusion, nutrients application may have a good impact on plant performance under water stress, and decreasing amount of water applied through alterative irrigation improved yield of fruit. Therefore, this experiment signifies the importance of potassium application together with conserving in water application.

\footnotetext{
* Prof. Soil Sci. Dept. - Coll. of Agric. - Univ. of Baghdad - Iraq. ** Assoc. Prof. Soil Sci. Dept. - Coll. of Agric. - Univ. of Baghdad - Iraq.
} 


\section{INTRODUCTION}

The potato (Solanum tuberosum $\mathbf{L}$.) is the fourth most important world crop, after wheat, maize and rice (Spooner and Bamberg,

1 1994). It is a major source of inexpensive energy. It contains high levels of carbohydrates and significant amounts of vitamins $\mathrm{B}$ and $\mathrm{C}$ and other minerals. In Iraq, potato is one of the most important crops, average yields 15.84 t/ha (Hasham, 2009).

The crop is judiciously fertilized with $\mathrm{N}, \mathrm{P}$ and $\mathrm{K}$, and other elements, based mainly on practical experience as there is a lack of recommendations based on correlation research. Potato plants require much more potassium than many other vegetable crops.

Although most soils in Iraq are rich in K, potassium fertilizer should be applied to sustain high yields (Mahmood, 2006). An adequate supply of potassium strengthens stems to prevent lodging, increases yield and improves tuber quality. Potatoes require high levels of potassium in concentrations which are comparable to or greater than nitrogen (Tisdale et al., 1997 and Westermann, 1994). In a similar study Westermann (1994) and (Hard and Smith, 1966) . reported that dry matter of potatoes decreased with increasing $\mathrm{K}$ level.

In arid and semiarid regions, potato is sensitive to water stress and irrigation has become an essential component of potato production in comparison with the other crops. Potato may be quite sensitive to drought (Van loon, 1981) as it needs frequent irrigation for suitable growth and optimum yield (Yan, et al.2003 and Kiziloglu, et al. 2006). Thornton (2002) and Shock (2004) found that all growing stages of potato, especially tuber formation stage, are very sensitive to water deficit stress. Water supply and scheduling have important impacts on tuber quality frequent irrigation reduces the occurrence of tuber malformation. Water deficit in the early phase of yield formation increases the occurrence of spindled tubers. Using good agricultural practices, including irrigation when necessary, a crop of about 120 days in temperate and subtropical climates can yield 25 to 40 tons of fresh tubers per hectare (FAO, 2008). The potato is extensively cultivated in large area of Iraq; but the effect of water stress on yield of this cultivar has not been investigated. Therefore, the objective of this study was to evaluate the effect of different rates of 
potassium sulfate $\left(\mathrm{K}_{2} \mathrm{SO}_{4}\right)$ on plant vegetative performance, total yield and WUE of potatoes grown under water stress.

\section{MATERIALS AND METHODS}

The experiment was carried out during spring seasons of 2009 at the Agricultural Research Station of Abu-Graib- Baghdad, Iraq (33 $20^{\prime} \mathrm{N}$, $44^{\circ} 12^{\prime}$ E; elev. $34.1 \mathrm{~m}$ ). Potato (Solanum tuberosum L.) was planted on soil of silt clay loam texture (Sand $=150 \mathrm{~g} \mathrm{~kg}^{-1}$, Silt=570 $\mathrm{g} \mathrm{kg}^{-1}$ and Clay $=284 \mathrm{~g} \mathrm{~kg}^{-1}$ ) with average bulk density of $1.41 \mathrm{Mg} \cdot \mathrm{m}^{-3}$ and soil content moisture $0.31 \mathrm{~cm}^{3} \mathrm{~cm}^{-3}$ at field capacity and wilting point equal $0.16 \mathrm{~cm}^{3} \mathrm{~cm}^{-3}$. The contents of nutrition in soil (available N, P and $\mathrm{K}$ are 267, 285 and $10.21 \mathrm{mg} . \mathrm{kg}^{-1}$, respectively). During the cultivation seasons; the mean relative humidity was $45 \%$ and mean rainfall was $18.17 \mathrm{~mm}$ during potato growing season. The total soil water was calculated between field capacity and wilting point for an assumed potato root extracting depth ranging from 0.15 to $0.45 \mathrm{~m}$.

Planting took place on 7 February using seeding rate of $2000 \mathrm{~kg} \cdot \mathrm{ha}^{-1}$ in $75 \mathrm{~cm}$ spaced rows with net plot size of $12 \mathrm{~m} \times 4.5 \mathrm{~m}$, in a randomized complete block design with three replicates. Each experimental unit consisted of 6 rows. All plots were irrigated with river water of $\mathrm{ECi}=1.1$ $\mathrm{dS} . \mathrm{m}^{-1}$. Irrigations were scheduled when soil water content in the root zone was depleted by the crop to specific fraction of the available water (irrigation was imposed at $50 \%$ and $75 \%$ depletion of available water). The soil depth of the effective root zone is increased from $0.15 \mathrm{~m}$ at planting to $0.45 \mathrm{~m}$ in bulking and tuber enlargement stages. Measured amounts of water were delivered to the furrows using water meter. Soil water content was measured gravimetrically. The sum of differences in soil water and applied irrigation water plus rainfall were calculated as ETa using water balance equation, assuming negligible deep percolation, groundwater contribution and runoff $(E T=P+I-D \pm \Delta W)$.

All plots received basic application of $300 \mathrm{~kg} \mathrm{~N}$ and $250 \mathrm{~kg} \mathrm{P}_{2} \mathrm{O}_{5} \mathrm{ha}^{-1}$. Four levels 0, 200, 400, and $600 \mathrm{~kg} \mathrm{~K}_{2} \mathrm{SO}_{4} \mathrm{ha}^{-1}$ were therefore studied. Granular fertilizers were hand spread before planting. Phosphorus source was di-ammonium phosphate, applied at once before planting. Nitrogen source was urea 46-0-0, split two times during growing season. 
During the growing season, plant height and leaf area were determined. Harvesting was carried out on 26 May, 2009. Potato tubers were then graded visually into marketable $(>3.5 \mathrm{~cm}$ in diameter) and cull $(<3.5 \mathrm{~cm}$, bruised, green or sprouted tubers). Marketable and total tuber yield were determined by weight, and only marketable tuber data is reported in this manuscript. Potato tuber samples were then collected from all treatments for specific gravity, percent carbohydrates and $\mathrm{K}$ content determinations. Reference evapotranspiration $\mathrm{ET}_{0}$ was calculated using PenmanMontieth modified equation (Allen, et al. 1998). Water - Use Efficiency (WUE) was calculated as fallows:

\section{Yield $(\mathrm{kg})$ \\ WUE $=0$ Tol water applied $\left(\mathrm{m}^{3}\right)$}

Statistical analysis: analysis of variance was performed to evaluate the statistical effect of irrigation treatment and $\mathrm{K}$ fertilizer application on potato yield and yield components using (SAS, 2002). LSD test was used to find any significant difference between treatment means.

\section{RESULTS AND DISCUSSIONS}

The results of Table 1 show that the addition of potassium fertilizer $\left(\mathrm{K}_{2} \mathrm{SO}_{4}\right)$ to soil has achieved an increase in vegetative growth of potato plant, lengths and plant leaf area index, and the increase was significant with the levels of irrigation in the study ( after depletion of 50 and $75 \%$ of available water). Plant height and leaf area reached to $85.76 \mathrm{~cm}, 41.22$ $\mathrm{cm}^{2}$. plant $^{-1}$ and $74.23 \mathrm{~cm}, 34.78 \mathrm{~cm}^{2}$.plant ${ }^{-1}$ in irrigation with $50 \%$ and $75 \%$ depletion of available water, respectively in $600 \mathrm{~kg} \mathrm{~K}_{2} \mathrm{SO}_{4} \mathrm{ha}^{-1}$ level. The reason for this increase with increased level of fertilizer added to soil, is due to the root composition becoming strong, active and efficient in the absorption of nutrients from the soil (Tisdale, et al. 1997) and increasing concentration in the shoots, leading to improved vegetative growth and increase in the efficiency of photosynthesis.

The results were similar to the attributes of the content of carbohydrates and potassium in the tuber with increase in the level of fertilizer potassium sulfate with two levels irrigation. Tuber potassium content 
increased significantly with $\mathrm{K}$ rates to reach a statistical maximum of $3.34 \%$ and $2.87 \%$ in irrigation with $50 \%$ and $75 \%$ depletion of available water, respectively at $\mathrm{K}$ rate of $600 \mathrm{~kg} \mathrm{~K}_{2} \mathrm{SO}_{4} \mathrm{ha}^{-1}$ (Table 1). Carbohydrate percent was increased significantly with increasing $\mathrm{K}$ rates. The highest level was reached with application of $600 \mathrm{~kg} \mathrm{~K}_{2} \mathrm{SO}_{4} \mathrm{ha}^{-1}$ to 12.69 and $11.74 \%$ in irrigation with $50 \%$ and $75 \%$ depletion of available water, respectively. The increase in potassium fertilizer caused a significant increase in the efficiency of the plant in the absorption of nitrogen, which plays a role in protein synthesis, transforms to the amino acids that move later places of manufacturing in the leaves to the storage places in the tubers to form protein, as well as the role of potassium in the process of protein synthesis (Tisdale, et al. 1997).

\section{Table 1. Effect of different levels of potassium sulfate and irrigation} level on plant height, leaf area, tuber specific gravity, carbohydrates, potassium concentration and marketable yield.

\begin{tabular}{|c|c|c|c|c|c|c|c|}
\hline $\begin{array}{c}\text { Irrigation level } \\
\text { (depletion of } \\
\text { AW) }\end{array}$ & $\begin{array}{c}\text { Treatment } \\
\mathrm{K}_{2} \mathrm{SO}_{4} \mathrm{~kg} \text { ha }^{-1}\end{array}$ & $\begin{array}{c}\text { Plant } \\
\text { height } \\
(\mathrm{cm})\end{array}$ & $\begin{array}{l}\text { Leaf area } \\
\left(\mathrm{cm}^{2} \operatorname{plan}^{-1}\right)\end{array}$ & $\begin{array}{l}\text { Specific } \\
\text { gravity }\end{array}$ & $\begin{array}{c}\text { Carbohyd } \\
\text { rates } \\
(\%)\end{array}$ & $\begin{array}{c}\mathrm{K} \\
(\%)\end{array}$ & $\begin{array}{c}\text { Marketable } \\
\text { tuber yield } \\
\left(\text { Ton } h^{-1}\right)\end{array}$ \\
\hline \multirow{4}{*}{$50 \%$} & 0 & 65.63 & 28.18 & 1.051 & 11.59 & 2.01 & 19.45 \\
\hline & 200 & 74.21 & 35.42 & 1.062 & 11.92 & 2.65 & 23.89 \\
\hline & 400 & 80.22 & 39.34 & 1.069 & 12.45 & 2.97 & 28.34 \\
\hline & 600 & 85.76 & 41.22 & 1.071 & 12.69 & 3.34 & 30.26 \\
\hline \multirow{4}{*}{$75 \%$} & $\mathbf{0}$ & 50.68 & 24.06 & 1.050 & 10.76 & 1.89 & 16.22 \\
\hline & 200 & 66.65 & 26.21 & 1.059 & 10.99 & 1.97 & 20.29 \\
\hline & 400 & 71.59 & 31.23 & 1.061 & 11.28 & 2.43 & 23.12 \\
\hline & 600 & 74.23 & 34.78 & 1.065 & 11.74 & 2.87 & 25.66 \\
\hline \multicolumn{2}{|c|}{ LSD (0.05) } & 4.85 & 2.04 & N.S & 0.23 & 0.18 & 1.75 \\
\hline
\end{tabular}

The availability of potassium in the phase of composition of the tubers is important and essential for the transfer of materials manufactured in the leaves, especially carbohydrates to the tubers that are stored in the form originated. It should be noted that the potato plants are characterized by (Luxury consumption) in absorption of potassium to the point of 
recreational consumption (Chapman et al., 1992). Our results did agree with those of (Davenport and Bentley, 2001) and (Abdeldagir et al., 2003) who found that specific gravity did not respond to $\mathrm{K}$ application.

Marketable tuber yield increased significantly $(\mathrm{p}<0.05)$ with increasing $\mathrm{K}$ rates up to $600 \mathrm{~kg} \mathrm{~K}_{2} \mathrm{SO}_{4} \mathrm{ha}^{-1}$. Higher $\mathrm{K}$ rates did improve yield to 30.26 and 25.66 t.ha $^{-1}$ in irrigation with 50 and $75 \%$ depletion of available water, respectively.

Negative effect of water stress on potato growth, quality and yield by increased application rates of $\mathrm{K}$ showed the role of $\mathrm{K}$ in the composition of cells Alsklarnkami most thicker and hardness and are resistant to conditions of water scarcity (drought) its role in the process of closing and opening gaps Securities (Pissarek, 1993). Also the effect of $K$ in proline acid concentration has special importance in regulation of water uptake by plants.

Table (2) shows the amounts of applied irrigation water under water stress during the growth of potato. Total water supplies were 410, 404, 400, 400; 375, 370, 365, $365 \mathrm{~mm}$ for 0.0, 200, 400 and $600 \mathrm{~kg} \mathrm{~K}_{2} \mathrm{SO}_{4} \mathrm{ha}^{-}$ ${ }^{1}$ treatments in $50 \%$ and $75 \%$ depletions, respectively. The amounts of irrigation water in different treatments were similar to those reported by Onder et al. (2005) and Erdem et al. (2006) with experiment carried out near the area of this study.

Table 2. Actual evapotranspiration (ETa) (mm), (WUE) $\left(\mathrm{kg} \mathrm{m}^{-3}\right)$

from water stress in cropping.

\begin{tabular}{|c|c|c|c|c|c|c|}
\hline $\begin{array}{c}\text { Irrigation } \\
\text { level } \\
\text { (depletion } \\
\text { of } A W)\end{array}$ & $\begin{array}{l}\text { Treatment } \\
\text { kg } \\
\mathrm{K}_{2} \mathrm{SO}_{4} \text { ha }^{-1}\end{array}$ & $\begin{array}{l}\text { Irrigation } \\
\text { (I) } \mathrm{mm}\end{array}$ & $\begin{array}{c}\text { Rain } \\
\text { fall } \\
(R) \\
\mathrm{mm}\end{array}$ & $\begin{array}{c}\text { (ETa) Actual } \\
\text { evapotranspiration } \\
\text { mm }\end{array}$ & $\begin{array}{c}\text { WUE } \\
\mathbf{k g} \\
\mathbf{m}^{-3}\end{array}$ & $\begin{array}{l}\text { Irrigation } \\
\text { water } \\
\text { saving } \\
(\%)\end{array}$ \\
\hline \multirow{4}{*}{$50 \%$} & $\overline{0}$ & 4410 & 18.71 & 429 & 5.0 & - \\
\hline & 200 & 404 & 18.71 & 423 & 6.0 & 1.0 \\
\hline & 400 & 400 & 18.71 & 419 & 7.0 & 2.0 \\
\hline & 600 & 400 & 18.71 & 419 & 8.0 & 2.0 \\
\hline \multicolumn{2}{|c|}{ mean } & 404 & 18.71 & 423 & & 1.67 \\
\hline \multirow{4}{*}{$75 \%$} & 0 & 375 & 18.71 & 394 & 4.0 & - \\
\hline & 200 & 370 & 18.71 & 389 & 5.0 & 1.0 \\
\hline & 400 & 365 & 18.71 & 384 & 6.0 & 3.0 \\
\hline & 600 & 365 & 18.71 & 384 & 7.0 & 3.0 \\
\hline \multicolumn{2}{|c|}{ mean } & 369 & 18.71 & 388 & & 2.33 \\
\hline
\end{tabular}


The cumulative ETa under different water treatments are also presented in Table 2. The mean $\mathrm{ET}_{\mathrm{a}}$ measured during the season, was $404 \mathrm{~mm}$ for $50 \%$ depletion of AW and $369 \mathrm{~mm} 75 \%$ depletion of AW. Water use efficiency (WUE) and rainfall, expressed as the ratio of potato yield to water supply from planting to harvest, varied typically comparable to those obtained in other field studies (Bowen, 2003) who reported that range of WUE was from 5 to $14 \mathrm{~kg} \mathrm{~m}^{-3}$.

The net saving in irrigation water with irrigation scheduling under $\mathrm{K}$ fertilizers application reached 8\% (Table 2). Cumulative ETo calculated from Penman-Monteith modified equation totaled $472 \mathrm{~mm}$ which are close to the ETa $(404,369 \mathrm{~mm})$ proved the validity of this equation for estimating the water requirements of potato within the context of the region.

\section{CONCLUSION AND RECOMMENDATION}

Both plant nutritional status and tuber quality parameters responded positively to increasing $\mathrm{K}$ application rates and water stress. Marketable tuber yield was significantly affected by $\mathrm{K}$ fertilizer levels. Highest yield and other quality parameters were achieved when a rate of $600 \mathrm{~kg} \mathrm{~K}_{2} \mathrm{SO}_{4}$ $\mathrm{ha}^{-1}$ was used. We recommend that, for similar regions in Iraq, farmers apply potassium sulfate at the rate $600 \mathrm{~kg} \mathrm{~K}_{2} \mathrm{SO}_{4} \mathrm{ha}^{-1}$ for optimum yield. More researchers are needed to investigate the benefits of further splitting of $\mathrm{K}$ fertilizer for potatoes grown in the different soil textures under arid conditions of Iraq.

\section{REFERENCES}

Abdeldagir, A. H.; M. A. Errebhi; H. M. Al Sarhan, and M. Ibrahim, (2003), The effect of different levels of additional potassium on yield and industrial qualities of potato (Solanum tuberosum L.) in an irrigated arid region. Amer. J. Potato Res. 80:219-222. 
Allen, R.G.; L.S. Perira; D. Raes and M. Smith, (1998), Crop Evapotranspiration. FAO Irrigation and Drainage paper 56, Rome.20-25.

Arab Organization for Agricultural Development.2006. (C. F. PhD Thes., Omar Hasham. 2009. Univ. of Baghdad. Coll. of Agr.).

Bowen, W.T., (2003), Water productivity and potato cultivation. In water productivity in agriculture: limits and opportunities for improvement. Ed. J. W. Kinje, R. Baker and D. Molden. CAB: 229-238.

Chapman, K. S. R.; L. A. Sparrow; P.R. Hardman; D. N. Wright and J.R. A. Thorp, (1992), Potassium nutrition of Kennebec and Russet Burbank potatoes in Tasmania: Effect of soil and fertilizer potassium on yield, petiole and tuber potassium concentrations and tuber quality. Australian J. Exp. Agric. 32:521-527.

Davenport, J. R., and E. M. Bentley, (2001) Does potassium fertilizer form, source, and time of application influence potato yield and quality in Columbia basin. Amer. J. Potato Res. 78:311-318.

Erdem, T.; Y. Erdem; H. Orta and H. Okursoy, (2006), Water - yield relationships of potato under different irrigation methods and regimes. Sci. Agric. 63(3):226-231.

Hart, T. G. and O. Smitm, (1966), Effect of levels sources of potassium on absorption of phosphorus by potatoes. Lants. Amer. Potato J. 43:217-235.

International Year of the Potato, (2008), Potato and water resources, Secretariat FAO. E-mail: potato2008@fao.org.

Kiziloglu, F.M.; U. Sahin; T. Tune and S. Diler, (2006). The effect of deficit irrigation on potato evapotranspiration and tuber yield under 
cool season and semiarid climatic conditions. J. Agron., 5: 284288.

Mahmood, J. T, (2006), Effect of NPK addition and foliar application on growth, yield and components of potato plants tubers. MSC Thes. Univ. of Baghdad. Coll. of Agric.70-77.

Onder, S.; M. Caliskan; D. Onder and S. Caliskan (2005). Different irrigation methods and water stress effects on potato yield and yield components. Agric. Water Manage. 73:73-86.

Omar, H. M. (2009), Use of animal manures and whey as a system for organic farming and it effect on growth and production of potatoes. PhD Thes. Univ. of Baghdad. Coll. of Agric.1-3.

Pissarek, H. P., (1993), The development of potassium deficiency symptoms in spring rape. 2- Pfanzmerahr. Bodenk. 136:1-96.

SAS, (2002), SAS Users guide, Statistics SAS, Inst.Gary,N.C.,U.S.A.

Shock, C.C, (2004), Efficient irrigation scheduling. Malheur Exp.St. Oregon St. Univ., Oregon, USA. 55-100

Spooner, D. M. and J. B. Bamber, (1994).. Potato genetic resources: sources of resistance and systematic. Amer. Potato J.71:325-338.

Thornton, M.K, (2002), Effects of heat and water stress on the physiology of potatoes. Idaho Potato Conf., Idaho. 23-88.

Tisdale, S. L., W. N. Nelson and J. D. Havlin, (1997), Soil Fertility and Fertilizers. Prentice-Hall New Delhi.113-145.

Van Loon, C.D, (1981), The effect of water stress on potato growth, development and yield. Am. Potato J., 58: 51-69.

Westermann, D. T.; D. W. James; T.A. Tindall and R. L. Hurst, (1994), Nitrogen and potassium fertilization of potatoes: Yield and specific gravity. Amer. Potato J.71:417-432. 
Yuan, B.Z.; S. Nishiyama and Y. Kang, (2003), Effects of different irrigation regimes on the growth and yield of drip-irrigated potato. Agric. Water Manag., 63: 153-167.

الملخص العزبي

تأثير التسميد بالبوتاسيوم في نمو وحاصل البطاطا وكفاءة استعمال المياه تحت معاملات الري

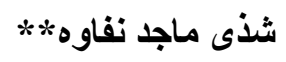

*اءع صالح عاتي

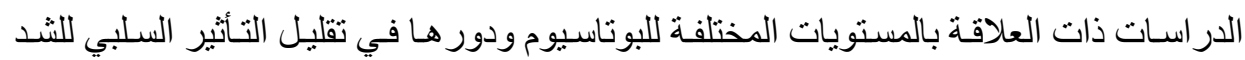

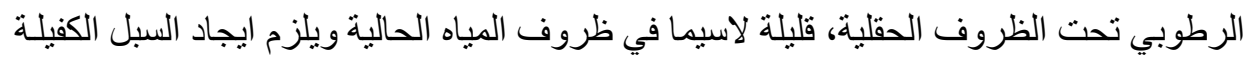

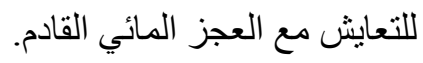

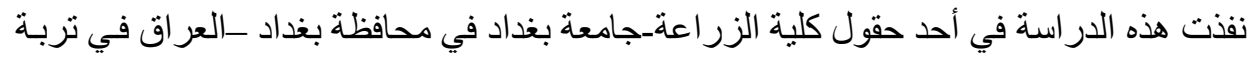

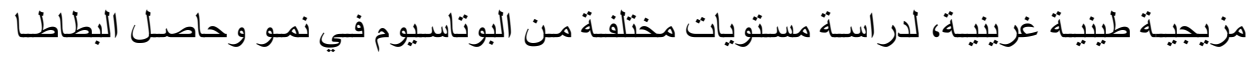
لتقليل التأثير السلبي للثد الرطوبي. (Solanum tuberosum L.)

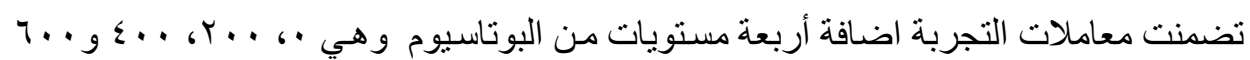

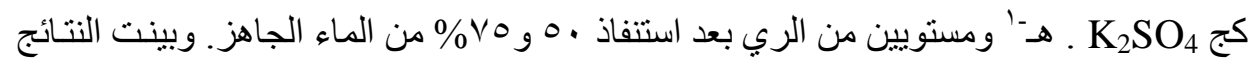
الآتي:-

1 إختز ال التأثيرات السلبية للثند الرطوبي (عجز الميـاه) في كميـة حاصل النبات ومعدل نموه

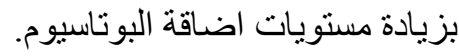

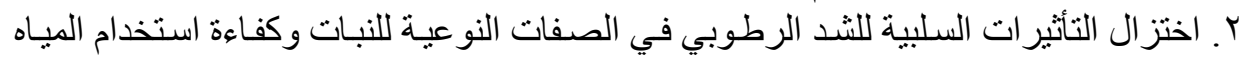

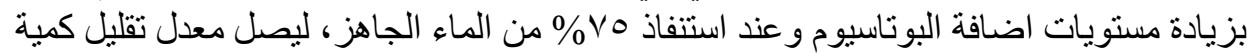

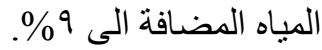

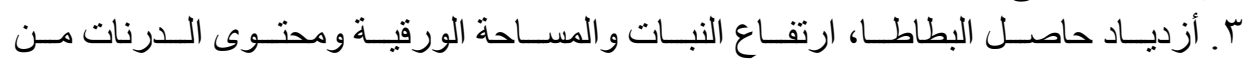

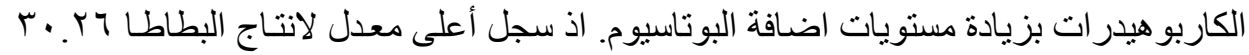

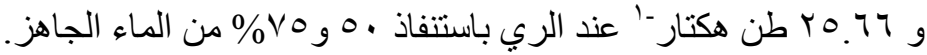

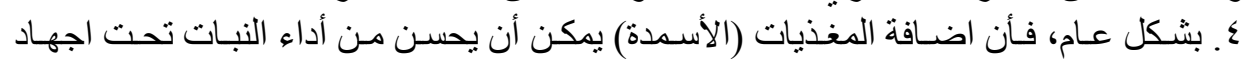
رطوبي معتدل وأن يزيد كفاءة استخدام المياه ويقلل المياه المضافة الناف.

* أستاذ ، قسم علوم التربة والمياه ـ كلية الزراعة / جامعة بغداد / العراق. ** أستاذ مساعد ، ، قسم علوم التربة والمياه ـ كلية الزراعة / جاعة جامعة بغداد / العراق. 